\title{
Regulation of cardiac oxytocin system and natriuretic peptide during rat gestation and postpartum
}

\author{
S Mukaddam-Daher, M Jankowski, D Wang, A Menaouar \\ and J Gutkowska
}

Laboratory of Cardiovascular Biochemistry, Centre Hospitalier de l'Université de Montréal Research Center, Campus Hôtel-Dieu, Pavilion de Bullion 6-816, 3840 St-Urbain Street, Montréal, Québec H2W 1T8, Canada

(Requests for offprints should be addressed to S Mukaddam-Daher; Email: suhayla.mukaddam-daher@umontreal.ca)

\begin{abstract}
We have recently uncovered the presence of an oxytocin system in the heart and found that oxytocin is a physiological regulator of atrial natriuretic peptide (ANP), a diuretic, natriuretic and vasodilator cardiac hormone. However, dynamic changes in these systems during gestation, when mechanisms of volume and pressure homeostasis are altered, are not clear. Accordingly, ANP, oxytocin and oxytocin receptors were evaluated in rat hearts and plasma at three stages of gestation (7, 14 and 21 days) and at 2 and 5 days postpartum. Compared with non-pregnant controls, plasma ANP was elevated in midgestation, but significantly decreased at term (21 days), to increase again postpartum. Right and left atrial ANP mRNA levels were not altered throughout gestation but increased by 1.5 - to 2 -fold postpartum $(P<0 \cdot 01)$. At term, ANP content in right $(8.7 \pm 1.2$ vs $12.7 \pm 1.1 \mu \mathrm{g} / \mathrm{mg}$ protein, $P<0 \cdot 04)$ and left $(3 \cdot 5 \pm 0 \cdot 6$ vs $8 \cdot 5 \pm 2 \cdot 0 \mu \mathrm{g} / \mathrm{mg}$ protein, $P<0 \cdot 01)$ atria increased. These findings imply that
\end{abstract}

decreased plasma ANP at term results from inhibition of release rather than decreased synthesis. In parallel, oxytocin, a stimulator of ANP release, decreased in left atria at day 7 to $50 \%$ of non-pregnant levels and remained low throughout gestation. Oxytocin receptor mRNA increased in left atria at 7 and 14 days of gestation by 2and 5 -fold respectively, but decreased at 21 days to lower than non-pregnant levels to increase again (3-fold) postpartum. The changes in oxytocin receptor expression at term and postpartum paralleled oxytocin receptor protein determined by Western blot. These results imply that pregnancy is associated with dynamic changes in the cardiac oxytocin system (peptide and/or receptors), which may influence natriuretic peptide release. Together, these peptides would act on their receptors in the heart, vasculature and kidneys to maintain vascular tone and renal function throughout gestation and postpartum.

Journal of Endocrinology (2002) 175, 211-216

\section{Introduction}

Hormonal regulation of blood pressure and volume homeostasis is altered in pregnancy. Despite a stimulated renin-angiotensin-aldosterone system, sympathetic overactivity and volume expansion, pregnancy is characterized by attenuated responsiveness to vasoconstrictive hormones, systemic vasodilation and lower blood pressure. Several factors, including reproductive hormones, natriuretic peptides, adrenomedullin, relaxin and oxytocin may, directly or indirectly, be involved in the maintenance of low pressure in pregnancy, through their vasodilatory and natriuretic properties (Adachi et al. 1995, Haanwinkel et al. 1995, Toth et al. 1996, Saita et al. 1998).

There is ample evidence that estrogen decreases blood pressure (Rosenfeld et al. 2000). Estrogen impairs constriction and augments dilation of arteries and attenuates the pressor responsiveness to several vasoconstrictors (Sudhir et al. 1995) similar to the reduced responsiveness that occurs in normal pregnancy (Nakamura et al. 1988, Novak
\& Kaufman 1991). Progesterone may also be implicated in pregnancy refractoriness to angiotensin II. Progesterone down-regulates angiotensin II receptors in rat uterine smooth muscle independently of angiotensin II levels and it, directly or through a metabolite, might have the effect on vascular receptors in humans (Nakamura et al. 1988).

The actions of estrogen and progesterone are mediated by specific-binding sites present in vascular tissue (Taylor \& Al-Azzawi 2000, Critchley et al. 2001) and heart (Jankowski et al. 2001), through stimulation of endothelial nitric oxide and cGMP (Darkow et al. 1997, Rosenfeld et al. 2000), and through stimulation of the release and/or synthesis of cardiac natriuretic peptides and oxytocin.

The effect of estrogen on atrial natriuretic peptide (ANP) has been shown in several species. In sheep, plasma ANP increases early and remains elevated throughout gestation (Mukaddam-Daher et al. 1994) and in vivo atrial stretch-induced ANP release is stimulated during pregnancy (Javeshghani et al. 1995). In the rat, chronic treatment with estradiol increases ANP release from 
isolated atria (Kaufman 1995), stimulates atrial ANP mRNA, and increases plasma ANP levels (Jankowski et al. 2001). However, during rat gestation, plasma ANP decreases at term to lower than non-pregnant levels, despite elevated estradiol levels, which would suggest that factors other than estradiol may be involved in ANP release in rat pregnancy.

In vivo studies have also demonstrated that estradiol up-regulates hypothalamic oxytocin gene expression (Amico et al. 1995), and oxytocin receptor mRNA in uterus (Zingg et al. 1995), kidney (Breton et al. 1996) and vasculature (Jankowski et al. 2000). We have shown that the heart is an important site for oxytocin synthesis and release (Jankowski et al. 1998), and have demonstrated the presence of oxytocin receptor mRNA in the rat heart atria and ventricles (Gutkowska et al. 1997). However, it is not known whether estradiol or pregnancy would have effects on the oxytocin system in the heart, especially whether oxytocin may regulate cardiac natriuretic peptide production in vivo (Haanwinkel et al. 1995) and in vitro (Gutkowska et al. 1997).

In pregnancy, dynamic changes in estradiol and progesterone may influence cardiac natriuretic peptide and oxytocin. Together, these peptides would act on their receptors in the heart, vasculature and kidneys to maintain vascular tone and renal function throughout gestation and postpartum. Accordingly, natriuretic peptide, oxytocin and oxytocin receptors were evaluated in rat hearts and plasma at three stages of gestation and at 2 and 5 days postpartum.

\section{Materials and Methods}

\section{Animals}

Female Sprague-Dawley rats were purchased from Charles River (St Constant, Quebec, Canada). Animals were housed in a temperature- and light-controlled room with food and water available ad libitum. Experiments were performed following the approval of the Bioethics Committee of Hôtel-Dieu de Montréal, according to Canadian Guidelines.

Non-pregnant and timed-pregnant rats were killed by decapitation at days $6-7,13-14,20-21$ of gestation (at term), and at days 2 and 5 postpartum. Blood $(1 \mathrm{ml})$ was collected in pre-chilled tubes containing protease inhibitors in a final concentration: $1 \mathrm{mmol} / \mathrm{l}$ EDTA, $5 \mu \mathrm{mol} / 1$ pepstatin A and $10 \mu \mathrm{mol} / 1$ phenylmethylsulfonyl fluoride (Sigma Chemical Co., St Louis, MO, USA). Blood was centrifuged at $4{ }^{\circ} \mathrm{C}$ and plasma was stored at $-80{ }^{\circ} \mathrm{C}$. The hearts were immediately excised and left and right atria and ventricles were separated and frozen in liquid $\mathrm{N}_{2}$.

\section{Radioimmunoassays}

The tissues were homogenized in $0 \cdot 1 \mathrm{mmol} / 1$ acetic acid containing protease inhibitors (as above) at $4{ }^{\circ} \mathrm{C}$. After
$20 \mathrm{~min}$ of centrifugation at $30000 \mathrm{~g}$, supernatants were collected, aliquoted and stored at $-80{ }^{\circ} \mathrm{C}$. Immunoreactive ANP was determined by specific radioimmunoassay in serial dilutions of tissue homogenates, and in plasma after extraction by Sep-Pak C18 cartridges (Millipore, Mississauga, Ontario, Canada) as previously described (Gutkowska 1987, Mukaddam-Daher et al. 1994). This assay has a minimal detectable level of $7.5 \mathrm{pg} / \mathrm{ml}$ and intra- and interassay coefficients of variation that average $9 \%$ and $13 \%$ respectively. Oxytocin content was measured in serial dilution of cardiac tissue homogenates and extracted plasma, by radioimmunoassay as previously described (Jankowski et al. 1998), using specific oxytocin antibody (a generous gift from M Morris, Wright State University, Dayton, OH, USA) and synthetic oxytocin standards (Peninsula Laboratories, Belmont, CA, USA). This assay has a minimal detectable level of $3 \mathrm{pg} / \mathrm{ml}$ and intra- and interassay coefficients of variation that average $6 \%$ and $33 \%$ for a mean of $25 \mathrm{pg} / \mathrm{ml}$ respectively. Therefore, to avoid interassay variation, all samples from non-pregnant and timed-pregnant rats were measured simultaneously. Protein content of tissue homogenates was measured spectrophotometrically by a modification of the Bradford technique, using bovine serum albumin as a standard.

\section{Total RNA extraction and PCR}

ANP mRNA and oxytocin receptor mRNA were measured in rat hearts by semi-quantitative PCR as we have previously described (Gutkowska et al. 1997). In brief, total RNA was extracted from rat tissues by the Trizol reagent (Life Technologies Inc; GIBCO-BRL, Rockville, MD, USA). Genomic DNA in the RNA extracts was removed by DNAse treatment. First-strand cDNA was synthesized in a final volume $(40 \mu \mathrm{l})$ containing first-strand buffer, $2 \mu \mathrm{g}$ rat atrial or ventricular RNA, $2 \mu \mathrm{g}$ hexanucleotide primer (Amersham Pharmacia), and avian myeloblastosis virus reverse transcriptase $(12 \mathrm{U} / \mathrm{mg}$ RNA; Life Sciences, St Petersburg, FL, USA).

PCR amplification of the rat oxytocin receptor gene was performed using a primer pair separated by a large (over $12 \mathrm{~kb}$ ) intron, hence preventing amplification of any contaminating genomic DNA. The sequence of the forward primer corresponded to bases 2821-2840 of the oxytocin receptor gene. The reverse primer (bases 39273946) was complementary to an untranslated sequence of the oxytocin receptor gene. The cycle parameters for PCR were $1.5 \mathrm{~min}$ at $94{ }^{\circ} \mathrm{C}, 1.5 \mathrm{~min}$ at $65^{\circ} \mathrm{C}$, and $2 \mathrm{~min}$ at $72{ }^{\circ} \mathrm{C}$.

The PCR products were electrophoresed in $2 \%$ agarose in the presence of ethidium bromide. A similar procedure was applied for amplification of rat ANP mRNA and for $18 \mathrm{~S}$ mRNA, used as internal standard for semiquantitative gene expression analysis (Jankowski et al. 2001). Control RT-PCRs were conducted by omitting 
reverse transcriptase or RNA from the reaction mixture. Additional controls included DNAse treatment of RNA extracts before RT-PCR. The possibility that artificial products were amplified was further controlled by incomplete RT-PCRs, such as omission of DNA polymerase or one of the primers. Fluorescent bands were counted and analyzed with the Storm 840 Imaging System and ImageQuant software (Version 4.2; Molecular Dynamics, Sunnyvale, CA, USA). To validate the use of this RTPCR assay as a tool for semi-quantitative measurement of oxytocin receptor or ANP mRNA, dose-response curves were established for different amounts of total RNA extracted from atrial tissue, and the samples were quantified in the curvilinear phase of PCR amplification. These data were normalized to the corresponding values of $18 \mathrm{~S}$ RNA PCR products in the same samples.

\section{Immunoblotting}

Oxytocin receptors were identified by Western blot analysis performed on atrial membranes of non-pregnant and timed-pregnant rats and 2 and 5 days postpartum. Denatured membrane protein samples $(40 \mu \mathrm{g})$ were electrophoresed on $10 \%$ polyacrylamide gels followed by transfer to nitrocellulose (Hybond-P; Amersham, Arlington Heights, IL, USA). The membranes were incubated for $1 \mathrm{~h}$ with polyclonal rabbit anti-rat oxytocin receptor (RDI, Flanders, NJ, USA) diluted 1:1000. Blots were washed then incubated for $2 \mathrm{~h}$ with horseradish peroxidase-conjugated anti-rabbit IgG antiserum diluted 1:5000 in Tris-buffered saline and 5\% milk. Immunoreactive bands were visualized by the enhanced chemiluminescence (ECL) detection system (Amersham ECL Hyperfilm). The density of the oxytocin receptor bands was normalized to corresponding bands obtained by similar incubation with monoclonal anti- $\beta$-actin (Sigma Chemical Co.). Results are represented as percent of non-pregnant values.

\section{Statistical analysis}

Differences in data obtained from non-pregnant and timed-pregnant rats were assessed by one-way analysis of variance. A confidence level of $P<0.05$ was considered significant. All data are expressed as means \pm S.E.M.

\section{Results}

As expected, serum estradiol increased with the advance of rat gestation from $40 \pm 9 \mathrm{pmol} / 1$ at day $6-7$ to $158 \pm 25$ at days 20-21, then decreased to $45 \pm 8 \mathrm{pmol} / 14$ days postpartum. Progesterone increased progressively at days 7 and 14 (496 $\pm 75 \mathrm{pmol} / \mathrm{l})$, but decreased at day 20-21 to very low levels $(55 \pm 11 \mathrm{pmol} / \mathrm{l})$. Thus, compared with non-pregnant control rats, the ratio of estradiol to

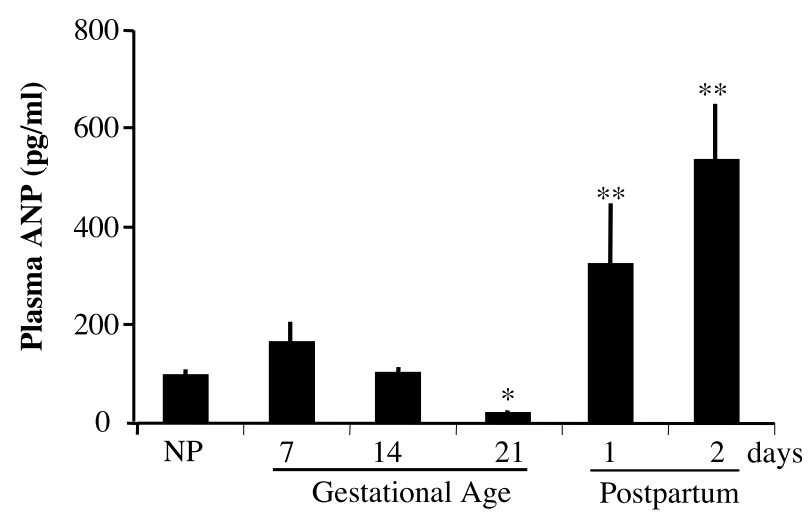

Figure 1 Plasma ANP in non-pregnant (NP) and pregnant rats at 7,14 and 21 days of gestation and at 1 and 2 days postpartum. ${ }^{*} P<0 \cdot 01$ vs non-pregnant controls; ${ }^{* *} P<0 \cdot 01$ vs day 21 of gestation. Values are means \pm S.E.M.

progesterone was highest (4-fold) at 21 days of gestation and immediately after parturition (3-fold).

Measurement of plasma ANP during the various stages of rat gestation revealed that compared with non-pregnant rats, ANP did not vary with the advance of gestation but significantly decreased at 21 days $(96 \cdot 7 \pm 12 \cdot 6$ to $23 \cdot 4 \pm$ $4.6 \mathrm{pg} / \mathrm{ml}, P<0 \cdot 01, n=21$ each), to increase 2 and 5 days postpartum $(458 \pm 85 \mathrm{pg} / \mathrm{ml}, n=7$ and $440 \pm 108 \mathrm{pg} / \mathrm{ml}$, $n=15$ respectively, $P<0 \cdot 01$ ) (Fig. 1 ).

Compared with non-pregnant controls, heart ANP content did not change on days 7 and 14 of gestation but increased on day 21 in right $(8 \cdot 7 \pm 1.2$ vs $12.7 \pm$ $1 \cdot 1 \mu \mathrm{g} / \mathrm{mg}$ protein, $P<0 \cdot 04)$ and left $(3.4 \pm 0 \cdot 6$ vs $8.5 \pm 2 \cdot 0 \mu \mathrm{g} / \mathrm{mg}$ protein, $P<0 \cdot 01)$ atria, to decrease postpartum to lower than non-pregnant control levels (Fig. 2). PCR determination revealed that right and left atrial ANP mRNA levels were not altered throughout gestation but increased by $1 \cdot 5$ - to 2 -fold postpartum $(P<0 \cdot 01)$. These results imply that regulation of plasma ANP during rat gestation primarily occurs on the level of secretion. Accordingly, the oxytocin system, a pregnancy-associated plasma ANP regulator, was investigated.

Plasma oxytocin averaged $32 \pm 6 \mathrm{pg} / \mathrm{ml}$ in nonpregnant control rats, and did not significantly vary with gestation or postpartum. Similarly, right atrial oxytocin content did not vary, but left atrial oxytocin decreased to $50 \%$ of non-pregnant levels $(P<0 \cdot 001)$ at day 7 and remained low throughout gestation, then returned to non-pregnant levels on the first day after parturition.

Regulation of oxytocin receptor in the heart was investigated on the level of synthesis and protein expression. Figure 3 shows that oxytocin receptor mRNA increased in left atria at 7 and 14 days of gestation by $2-$ and 5 -fold $(P<0 \cdot 02)$ respectively. In addition, left atrial oxytocin receptor mRNA decreased at 21 days to lower than non-pregnant control levels and increased (3-fold) postpartum. The variations in pregnancy-associated right 


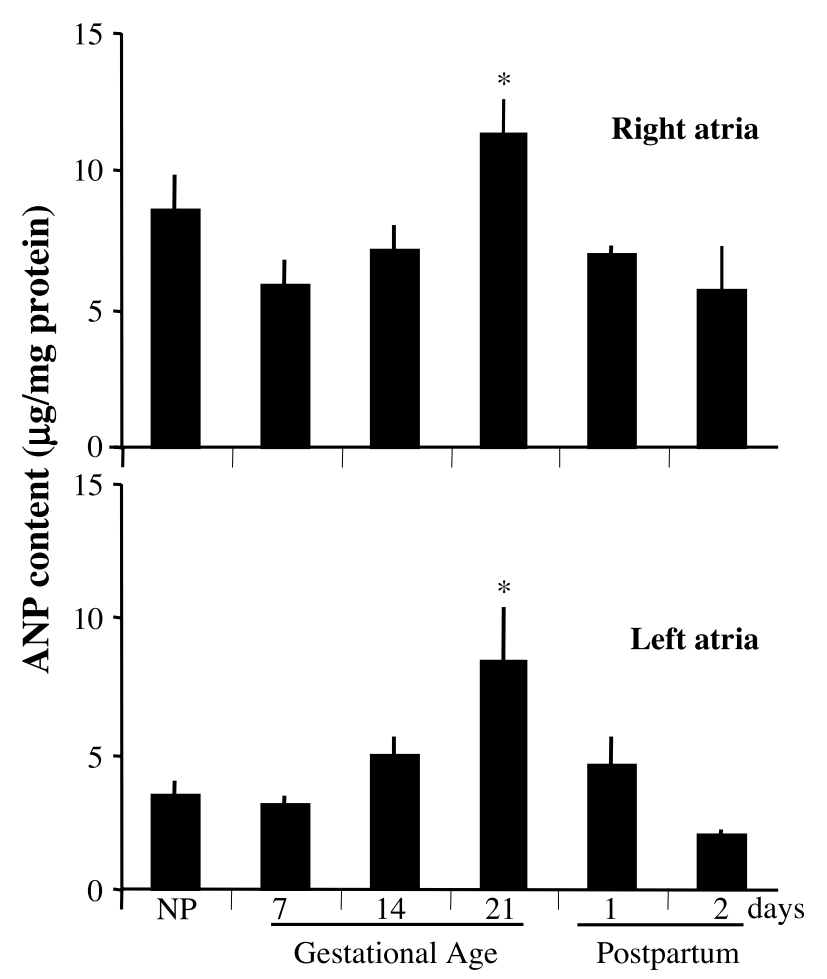

Figure 2 ANP content in right and left atrial tissue from non-pregnant (NP) and pregnant rats at 7, 14 and 21 days of gestation and at 1 and 2 days postpartum. ${ }^{*} P<0 \cdot 04$ vs non-pregnant controls. Values are means \pm S.E.M.

atrial oxytocin receptor mRNA paralleled those observed in left atria but were of a lesser magnitude. Regulation of oxytocin receptor was also investigated by Western blot analysis. This methodology allowed detection of the $66 \mathrm{kDa}$ oxytocin receptor protein in the rat uterus as well as its regulation with the advance of gestation and postpartum (Fig. 4A). Using similar conditions, immunoblotting confirmed that cardiac atria possess oxytocin receptors with a molecular weight similar to that present in the uterus. Quantification of the scanned oxytocin receptor bands revealed that, compared with corresponding nonpregnant values, atrial oxytocin receptor did not vary at 7 and 14 days of gestation, but significantly $(P<0 \cdot 002)$ decreased at 21 days to increase again postpartum (Fig. 4B).

\section{Discussion}

We have previously shown the presence of oxytocin and oxytocin receptors in all four heart compartments. The present study has shown that the cardiac oxytocin system is physiologically regulated. It undergoes dynamic changes during rat gestation and postpartum, decreasing at term

\section{Right atria}

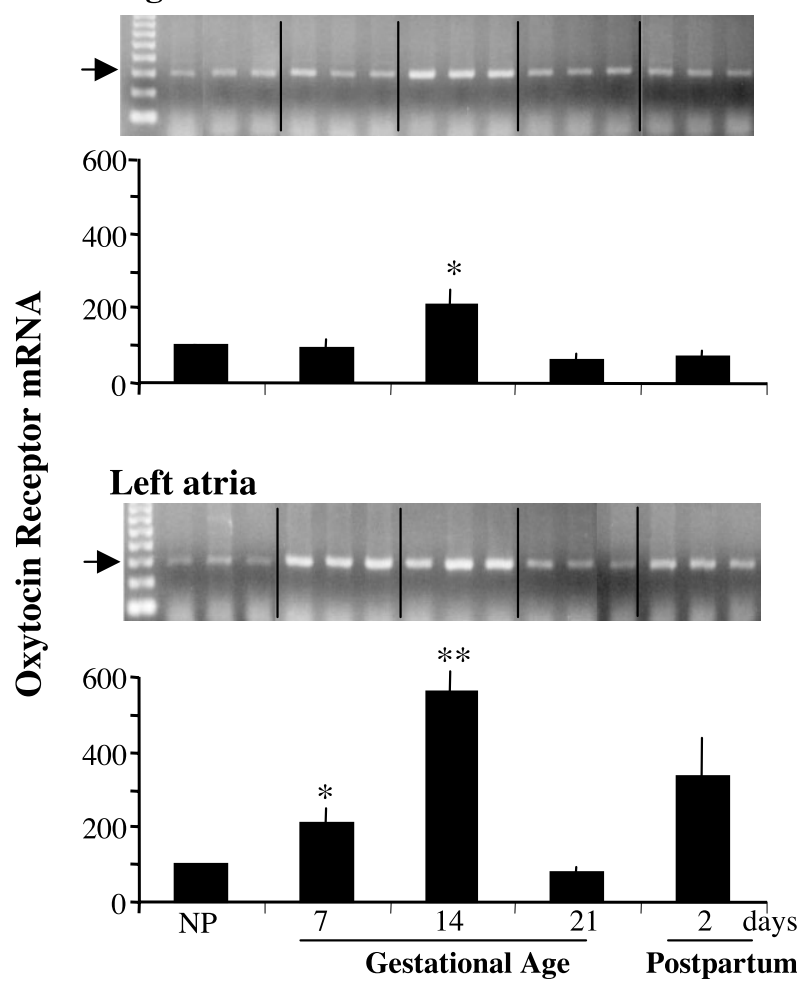

Figure 3 Representative photographs of oxytocin receptor RT-PCR products after electrophoresis of three RNA samples obtained from non-pregnant and pregnant rats at 7, 14 and 21 days of gestation and 2 days postpartum. The results are calculated as the ratio of the signals of oxytocin receptor mRNA bands to the corresponding $18 \mathrm{~S}$ bands. Bar graphs represent values normalized to non-pregnant levels expressed as $100 \%$. Arrows denote molecular weight of $373 \mathrm{bp} .{ }^{*} P<0 \cdot 04$ and ${ }^{* *} P<0 \cdot 02$ vs corresponding non-pregnant control. Values are means \pm S.E.M.

to increase again after parturition. Furthermore, these changes parallel changes in pregnancy-associated circulating ANP, a vasodilator and volume regulator cardiac hormone.

The mechanisms involved in the dynamic changes in plasma ANP during rat gestation, decreasing at term and increasing postpartum, are not yet clear. Atrial ANP synthesis did not significantly change during gestation, but atrial ANP content increased to highest levels at term, in contrast to lowest plasma levels. Since ANP is stored in granules in the atria, the present study showed that changes in plasma ANP during rat gestation mainly result from altered storage and release in addition to altered synthesis, and that intermediary factor(s) may be involved in stimulating or inhibiting the release of ANP. The intermediary factors may include several systems sensitive to the actions of female steroids and known to regulate ANP. Among these is the reproductive and cardiovascular hormone, oxytocin. 
A

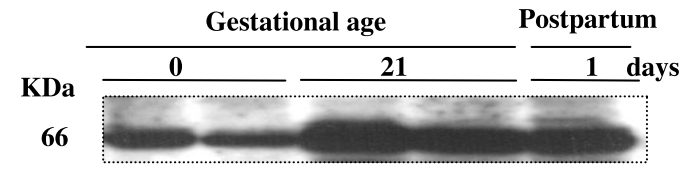

B

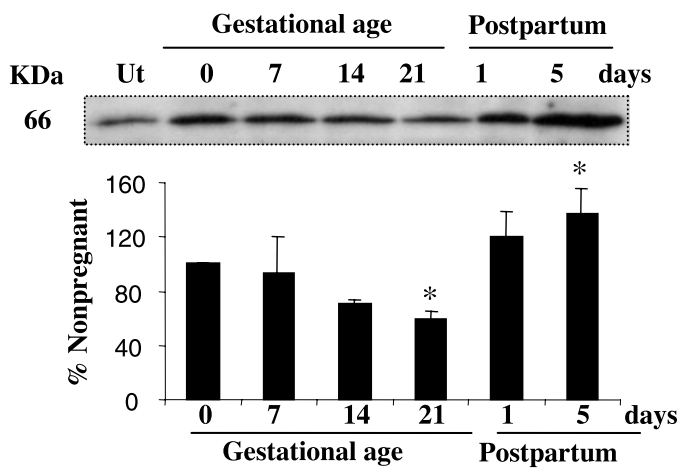

Figure 4 (A) Immunoblot analysis of oxytocin receptor protein in uterine membranes of non-pregnant and pregnant rats. (B) Representative immunoblot analysis of oxytocin receptor protein in atrial membranes of non-pregnant and pregnant rats at 7, 14 and 21 days of gestation and at 1 and 5 days postpartum. Bar graphs represent values obtained from six different experiments after normalization to corresponding $\beta$-actin values, then to non-pregnant levels, expressed as $100 \%$. Ut, uterine membranes included in the same gel as a positive control. Values are means \pm S.E.M.

Plasma oxytocin did not vary throughout pregnancy in the rat, but cardiac oxytocin and oxytocin receptors varied in parallel to plasma ANP. Both oxytocin and oxytocin receptors as well as plasma ANP decreased at term to increase again postpartum. Based on previous in vitro and in vivo studies showing that oxytocin may act on its receptors to stimulate ANP release (Haanwinkel et al. 1995, Gutkowska et al. 1997), it is reasonable to suggest that alteration in the cardiac oxytocin system may influence local ANP production and secretion, so that pregnancyassociated up-regulation of heart oxytocin and oxytocin receptors stimulates, and down-regulation reduces, ANP release.

The mechanisms involved in the regulation of the cardiac oxytocin system have not been presently investigated. However, previous studies have shown that variation in the oxytocin system in several organs is linked to the steroid environment (Amico et al. 1995, Uenoyama \& Okuda 1997, Blyth et al. 2000), and that an altered estradiol to progesterone ratio may differentially influence oxytocin receptor expression and protein (Ivell et al. 2001). During pregnancy, the number of oxytocin-binding sites in rat uterus increases by 10 -fold, reaching a maximum prior to parturition (Soloff et al. 1979), a finding confirmed by Western blot analysis in the present study. Also, in pregnant rats at term, oxytocin receptor mRNA is dramatically increased in the hypothalamus and uterus but decreases in the kidney (Breton et al. 1996). Uterine oxytocin receptor is down-regulated by progesterone treatment (Grazzini et al. 1998), and the decline in progesterone is necessary for the expression of the stimulatory effect of estrogen on uterine mRNA (Murata et al. 2000). In conditions of an elevated estradiol to progesterone ratio, i.e. conditions that mimic pregnancy at term, oxytocin receptor mRNA is increased in pituitary (Amico et al. 1995) and uterus (Zingg et al. 1995) and the increase in hypothalamic oxytocin receptor mRNA is attenuated by allopregnanolone (Blyth et al. 2000). Allopregnanolone binds to $\gamma$-aminobutyric acid $(\mathrm{GABA})_{\mathrm{A}}$ receptor/ $\mathrm{Cl}^{-}$ channels and enhances GABA tone. GABA, an inhibitory neurotransmitter, is known to inhibit the oxytocin system (Blyth et al. 2000). Therefore, it is likely that the downregulated cardiac oxytocin system at term may be influenced by elevated allopregnanolone levels (Luisi et al. 2000).

Sex steroids may also act indirectly on both oxytocin and oxytocin receptor genes, possibly through intermediate transcription factors or cofactors (Ivell \& Walther 1999). At term, estrogen and interleukin-6 have been suggested to modulate oxytocin receptor gene expression and both are elevated at the time of parturition (Young et al. 1997). Interleukin-1 down-regulates uterine oxytocin receptor in a time- and dose-dependent fashion (Rauk \& Friebe-Hoffmann 2000). Regardless of the mechanisms controlling the cardiac oxytocin system, it is interesting to note that inhibited cardiac oxytocin or oxytocin receptors in rat heart at term is consistent with increased heart rate and force of contraction observed in term pregnancy. We have shown, in superfused isolated dog atria, that oxytocin exerts negative inotropic and chronotropic effects (Mukaddam-Daher et al. 2001).

In conclusion, during pregnancy, reproductive hormones and transcription factors may regulate natriuretic peptide release, either directly or indirectly through regulation of the cardiac oxytocin system (peptide and/or receptors). After parturition, an activated oxytocin system may stimulate ANP production, which helps to rid the body of the excess volume. The heart, the major source of natriuretic peptides and an important source of oxytocin and their respective receptors as well as estrogen receptors, may be involved in blood pressure regulation through local interaction.

\section{Acknowledgements}

This work was supported by grants from The Canadian Institutes for Health Research (MT-11674 (to J G and S M-D) and MT-15049 (to M J and J G) and grants from the Heart and Stroke Foundation of Canada to S M-D and J G. 


\section{References}

Adachi K, Majima M, Katori M \& Nishijima M 1995 Oxytocininduced natriuresis mediated by the renal kallikrein-kinin system in anesthetized male rats. Japanese Journal of Pharmacology 67 243-252.

Amico JA, Crowley RS, Insel TR, Thomas A \& O’Keefe JA 1995 Effect of gonadal steroids upon hypothalamic oxytocin expression. Advances in Experimental Medicine and Biology 395 23-35.

Blyth BJ, Hauger RL, Purdy RH \& Amico JA 2000 The neurosteroid allopregnanolone modulates oxytocin expression in the hypothalamic paraventricular nucleus. American Journal of Physiology 278 R684-R691.

Breton C, Neculcea J \& Zingg HH 1996 Renal oxytocin receptor messenger ribonucleic acid: characterization and regulation during pregnancy and in response to ovarian steroid treatment. Endocrinology 137 2711-2717.

Critchley HO, Brenner RM, Henderson TA, Williams K, Nayak NR, Slayden OD, Millar MR \& Saunders PT 2001 Estrogen receptor beta, but not estrogen receptor alpha, is present in the vascular endothelium of the human and nonhuman primate endometrium. Clinical Endocrinology and Metabolism 86 1370-1378.

Darkow DJ, Lu L \& White RE 1997 Estrogen relaxation of coronary artery smooth muscle is mediated by nitric oxide and cGMP. American Journal of Physiology 272 H2765-H2773.

Grazzini E, Guillon G, Mouillac B \& Zingg HH 1998 Inhibition of oxytocin receptor function by direct binding of progesterone. Nature 392 509-512.

Gutkowska J 1987 Radioimmunoassay for atrial natriuretic factor. Nuclear Medicine and Biology 14 323-331.

Gutkowska J, Jankowski M, Lambert C, Mukaddam-Daher S, Zingg $\mathrm{HH} \&$ McCann SM 1997 Oxytocin releases atrial natriuretic peptide by combining with oxytocin receptors in the heart. PNAS 94 11704-11709.

Haanwinckel M, Elias L, Favaretto AL, Gutkowska J, McCann SM \& Antunes-Rodrigues J 1995 Oxytocin mediates atrial natriuretic peptide release and natriuresis after volume expansion in the rat. PNAS 92 7902-7906.

Ivell R \& Walther N 1999 The role of sex steroids in the oxytocin hormone system. Molecular and Cellular Endocrinology 151 95-101.

Ivell R, Kimura T, Muller D, Augustin K, Abend N, Bathgate R, Telgmann R, Balvers M, Tillmann G \& Fuchs AR 2001 The structure and regulation of the oxytocin receptor. Experimental Physiology 86 289-296.

Jankowski M, Hajjar F, Kawas SA, Mukaddam-Daher S, Hoffman G, McCann SM \& Gutkowska J 1998 Rat heart: a site of oxytocin production and action. PNAS 95 14558-14563.

Jankowski M, Wang D, Hajjar F, Mukaddam-Daher S, McCann SM \& Gutkowska J 2000 Oxytocin and its receptors are synthesized in the rat vasculature. PNAS 97 6207-6211.

Jankowski M, Rachelska G, Donghao W, McCann SM \& Gutkowska J 2001 Estrogen receptors activate atrial natriuretic peptide in the rat heart. PNAS 98 11765-11770.

Javeshghani D, Mukaddam-Daher S, Fan L, Gutkowska J, Nuwayhid B \& Quillen EW 1995 Control of atrial natriuretic factor by right and left atrial distension in pregnant sheep. American Journal of Physiology 268 R1411-R1417.

Kaufman S 1995 Control of intravascular volume during pregnancy. Clinical and Experimental Pharmacology and Physiology 22 157-163.
Luisi S, Petraglia F, Benedetto C, Nappi RE, Bernardi F, Fadalti M, Reis FM, Luisi M \& Genazzani AR 2000 Serum allopregnanolone levels in pregnant women: changes during pregnancy, at delivery, and in hypertensive patients. Journal of Clinical Endocrinology and Metabolism 85 2429-2433.

Mukaddam-Daher S, Gutkowska J, Nuwayhid BS \& Quillen EW 1994 Atrial natriuretic factor in ovine pregnancy: plasma levels, molecular forms and biological activity. Regulatory Peptides $\mathbf{5 1}$ 131-139.

Mukaddam-Daher S, Yin Y-L, Roy J, Gutkowska J \& Cardinal R 2001 Negative inotropic and chronotropic effects of oxytocin. Hypertension 38 292-296.

Murata T, Murata E, Liu CX, Narita K, Honda K \& Higuchi T 2000 Oxytocin receptor gene expression in rat uterus: regulation by ovarian steroids. Journal of Endocrinology 166 45-52.

Nakamura T, Matsui K, Ito M, Yoshimura T, Kawasaki N, Fujisaki S \& Okamura H 1988 Effects of pregnancy and hormone treatments on pressor response to angiotensin II in conscious rats. American Journal of Obstetrics and Gynecology 159 989-995.

Novak K \& Kaufman S 1991 Effects of pregnancy, estradiol, and progesterone on pressor responsiveness to angiotension II. American Journal of Physiology 261 R1164-R1170.

Rauk PN \& Friebe-Hoffmann U 2000 Interleukin-1 beta downregulates the oxytocin receptor in cultured uterine smooth muscle cells. American Journal of Reproduction and Immunology 43 85-91.

Rosenfeld CR, White RE, Roy T \& Cox BE 2000 Calciumactivated potassium channels and nitric oxide coregulate estrogeninduced vasodilation. American Journal of Physiology 279 H319-H328.

Saita M, Ishizuka Y, Kato K, Kunitake T, Hanamori T, Kitamura K, Eto T \& Kannan H 1998 Cardiovascular and sympathetic effects of proadrenomedullin $\mathrm{NH}_{2}$-terminal 20 peptide in conscious rats. Regulatory Peptides 77 147-153.

Soloff MS, Alexandrova M \& Fernstrom MJ 1979 Oxytocin receptors: triggers for parturition and lactation? Science $2041313-1315$.

Sudhir K, Chou TM, Mullen WL, Hausmann D, Collins P, Yock PG \& Chatterjee K 1995 Mechanisms of estrogen-induced vasodilation: in vivo studies in canine coronary conductance and resistance arteries. Journal of the American College of Cardiology 26 807-814.

Taylor AH \& Al-Azzawi F 2000 Immunolocalisation of oestrogen receptor beta in human tissues. Journal of Molecular Endocrinology 24 145-155.

Toth M, Taskinen P \& Ruskoaho H 1996 Relaxin stimulates atrial natriuretic peptide secretion in perfused rat heart. Journal of Endocrinology 150 487-495.

Uenoyama Y \& Okuda K 1997 Regulation of oxytocin receptors in bovine granulosa cells. Biology of Reproduction 57 569-574.

Young LJ, Muns S, Wang Z \& Insel TR 1997 Changes in oxytocin receptor $\mathrm{mRNA}$ in rat brain during pregnancy and the effects of estrogen and interleukin-6. Journal of Neuroendocrinology 9 859-865.

Zingg $\mathrm{HH}$, Rozen F, Breton C, Larcher A, Neculcea J, Chu K, Russo C \& Arslan A 1995 Gonadal steroid regulation of oxytocin and oxytocin receptor gene expression. Advances in Experimental Medicine and Biology 395 395-404.

Received 7 June 2002

Accepted 3 July 2002 